\title{
RECONHECENDO A DÍVIDA AO JUSNATURALISMO E SUA CONTRIBUIÇÃO AO DIREITO INTERNACIONAL PENAL
}

RECOGNIZING THE DEBIT TO THE IUSNATURALISM AND ITS
CONTRUBUTION TO THE INTERNATIONAL CRIMINAL LAW

Carlos Augusto Canedo Gonçalves da Silva ${ }^{1}$ PUC Minas Roberta Cerqueira Reis ${ }^{2}$ PUC Minas

\section{Resumo}

Este artigo visa resgatar o debate entre positivismo jurídico e jusnaturalismo no contexto do Direito Internacional. São abordadas as origens jusnaturalistas do direito das gentes, com Hugo Grotius e Francisco de Vitória. O artigo debate, ainda, como a dívida do Direito Internacional para com o Direito Natural não se restringe à sua história, mas se encontra presente no sistema internacional moderno, pós Segunda Guerra Mundial, fundado na lógica da universalização dos Direitos Humanos. Aborda-se ainda a maneira como o jusnaturalismo está nas bases do Direito Internacional Penal, seja através da tipificação do crime contra a humanidade ou através do princípio da imputação individual. Realiza-se uma breve revisão bibliográfica acerca da relação do Direito Natural com o Direito Internacional - jus cogens e os Direitos Humanos, utilizando-se autores como Cançado Trindade, Jack Donnelly e Hannah Arendt. Objetiva-se, com este escrito, reacender o debate acerca da centralidade do jusnaturalismo para a teoria do Direito Internacional, superando o preconceito oriundo de décadas de visão cientificista e positivista do Direito.

${ }^{1}$ Professor do Programa de Pós-graduação em Direito da Pontifícia Universidade Católica de Minas Gerais.

${ }^{2}$ Mestre em Direito Internacional pela Pontifícia Universidade Católica de Minas Gerais 


\section{Palavras-chaves}

Jusnaturalismo. Positivismo Jurídico. Direito internacional penal. Jus cogens. Direitos Humanos

\section{Abstract}

This paper aims to re-introduce the debate between legal positivism and natural law in international law. It discusses the origins of jus-naturalism in the droit des gens, with Hugo Grotius and Francisco de Vitória. This article debates, also, how international law is in debt with Natural Law not only for its history, but also in modern day international system, post-World War II, embedded in universal human rights. It approaches how jus-naturalism is at the foundation of international criminal law, be it in the typology of crimes against humanity or in the principle of criminal personal responsibility. It takes a brief bibliographical review relating to Natural Law, International Law - jus cogens and Human Rights, referring to authors such as Cançado Trindade, Jack Donnelly and Hannah Arendt. It seeks to debate the importance of jus-naturalism for International Law theory, overcoming the prejudice originated in decades of a scientificist and positivist approach to Law.

\section{Keywords}

Natural Law. Legal Positivism. International Criminal Law. Jus cogens. Human Rights.

\section{INTRODUÇÃO}

O pensamento jurídico ocidental é dominado pelo vívido debate entre os chamados "direito positivo" e "direito natural". (BOBBIO, 1995). No cerne da distinção entre "positivo" e "natural" está a ideia de algo que é colocado pelo homem, convencionado, em contraposição a algo que é inerente, de ordem natural.

Neste cenário de crescente embate ousamos analisar o Direito Internacional e sua posição de catalisador destas tensões, especialmente, devido à suas origens históricas e vocação universalizante (dívida histórica com o jusnaturalismo) em 
contraposição a uma tendência atual de positivação e codificação das normas internacionais (influência positivista).

O sistema internacional moderno, estabelecido pós Segunda Guerra Mundial se estrutura na lógica da internacionalização dos Direitos Humanos, que concedeu tutela a nível internacional aos indivíduos que por ventura sofram violações por parte de seus Estados.

A lógica do chamado Direito Internacional dos Direitos Humanos, estampada logo no preâmbulo da Declaração Universal dos Direitos Humanos, é a universalidade destes direitos "considerando que o reconhecimento da dignidade inerente a todos os membros da família humana e de seus direitos iguais e inalienáveis é o fundamento da liberdade, da justiça e da paz no mundo (...)".

Direitos Humanos se aplicam independentemente do local, do governo, da cultura ou da vontade de seu destinatário. Não se trata de Direitos dos Estados, são direitos destinados à "família humana" e existem pelo simples fato de se tratar de um ser humano. Uma conotação essencialmente jusnaturalista, que denota algo inerente aos homens, natural e que independe de positivação.

Para tanto, iniciamos este artigo pontuando o debate histórico entre o jusnaturalismo e o positivismo jurídico, concluindo pela maneira como no decorrer do último século o jusnaturalismo perdeu seu status de "Direito" para o positivismo e sua pretensão de neutralidade científica.

Em seguida passamos a demonstrar a dívida do Direito Internacional para com o jusnaturalismo seja em sua fundação histórica seja na forma como o sistema internacional se organiza nos dias atuais. Discutimos, brevemente, como a tese voluntarista sobre o direito internacional tornou o sistema anárquico (mais) inseguro e imprevisível. Mostramos ainda, a existência de valores no sistema que constrangem e modificam o comportamento dos Estados, 
representando verdadeira mudança paradigmática do voluntarismo para uma busca de objetivos comuns.

A própria ideia de jus cogens, discutiremos, expressa uma "consciência jurídica internacional" acerca da proteção dos vulneráveis, base obviamente jusnaturalista e que se coloca como norma imperativa de Direito Internacional, nos termos do artigo 53 da Convenção de Viena sobre Direito dos Tratados.

Por fim, passamos a demonstrar como mesmo em áreas sensíveis do Direito Internacional, como o caso do Direito Internacional Penal, temos a dívida ao Direito Natural, seja pela tipificação de seus crimes (crime contra a humanidade), seja pelo princípio da Imputação Individual, que julga indivíduos e não Estados.

A lógica da punição internacional por crimes contra a humanidade se deve, justamente, a uma concepção universalista de que existe uma comunidade humana, interligada, e que é agredida por aquela ação. O bem jurídico tutelado, portanto, é a humanidade indistinta e não a vida da vítima direta.

A existência, hoje, de um Tribunal Penal Internacional que julga crimes contra a humanidade nada mais é que herança de um jusnaturalismo que existe no Direito Internacional, queiram os acadêmicos juristas reconhecê-la ou não.

Este artigo se pretende como um início de debate acerca da importância do jusnaturalismo para o Direito Internacional, superando os preconceitos tão arraigados por décadas de celebração de uma visão cientificista, positivista do Direito, enquanto disciplina objetiva e neutra.

\section{PONTUANDO O DEBATE: JUSNATURALISMO E POSITIVISMO JURÍDICO}


Uma distinção entre o direito natural (jusnaturalismo) e o direito positivo (positivismo) longe de ser um problema moderno, ganhou contornos já em Aristóteles que enumerava dois critérios para tal diferenciação. Para o filósofo o direito natural "é aquele que tem em toda parte (pantachou) a mesma eficácia (...), enquanto o direito positivo tem eficácia apenas nas comunidades políticas singulares em que é posto." (BOBBIO, 1995, p. 17)

O direito natural, originário da ordem natural das coisas, como uma lei da natureza que independe da intervenção humana. O fogo, por exemplo, queima em qualquer lugar do globo. O mesmo é válido para a tendência das coisas de serem atraídas para o centro da Terra, afinal, não podemos anular a lei da gravidade.

Para a existência das normas de direito natural independe o juízo humano acerca da sua adequação, pois a lei existirá independentemente da interferência humana (BOBBIO, 1995). Assim, os escolásticos medievais diriam que as normas de direito natural seriam boas em si mesmas, detentoras de uma bondade objetiva.

O direito positivo, por sua vez, trataria da regulação de ações que podem ser realizadas de várias formas. Um sacrifício animal (para usarmos o exemplo de Aristóteles) pode ser realizado de inúmeras maneiras, mas uma vez colocada norma regulando uma dada forma de realização deste sacrifício,ocorrerá a exclusão de todas as demais possibilidades.

A distinção essencial neste tocante é que o direito natural trata de um comportamento único, não há opções alternativas (a gravidade atua, gostemos ou não). Por sua vez, o direito positivo regula um comportamento, restringindo as inúmeras opções possíveis para aquela situação (posso sacrificar um animal de inúmeras maneiras, mas a lei pode determinar que isto seja feito de uma determinada forma). 
Os romanos trataram o tema separando o direito natural (jus gentium) e o direito positivos (jus civile). O jus civile, posto pelo homem, se aplicava a um povo especificamente, podendo ser modificado ou anulado, enquanto o jus gentium, decorrente de uma razão natural, não possuía limites, aplicando-se indiscriminadamente a todos os povos, imutável no tempo e no espaço.

Bobbio (1995, p.19) resume o pensamento de Paulo no Digesto:

a) o direito natural é universal e imutável (semper) enquanto o civil é particular (no tempo e no espaço);

b) o direito natural estabelece aquilo que é bom (bonum ET aequum), enquanto o civil estabelece aquilo que é útil: o juízo correspondente ao primeiro funda-se um critério moral, ao passo que o relativo ao segundo baseia-se num critério econômico ou utilitário.

No período medieval se manteve a tônica da distinção entre o direito natural e o direito positivo, sendo a característica de que o último é posto pelos homens e o primeiro é posto por algo (ou alguém) além dos homens, como a natureza (ou o próprio Deus). A teorização ganharia robustez nos séculos XVII e XVIII com Hugo Grotius, reconhecido como o pai do Direito Internacional e que assim elaborava a distinção:

O direito natural é um ditame da justa razão destinado a mostrar que um ato é moralmente torpe ou moralmente necessário segundo seja ou não conforme à própria natureza racional do homem, e a mostrar que tal ato é, em consequência disto, vetado ou comandado por Deus, enquanto autor da natureza. (GROTIUS apud BOBBIO, 1995, p. 20/21) 
Bobbio (1995) destaca que para Grotius o direito positivo seria aquele direito voluntário, posto pelo Estado, pela família ou pela Comunidade Internacional, enquanto o direito natural seria inafastável. Para Grotius:

O direito natural é tão inalterável que não pode ser mudado nem mesmo pelo próprio Deus. Embora o poder de Deus seja infinito, ainda assim existem coisas para as quais ele não atinge. Pois estas coisas não teriam um significado verdadeiro, implicariam uma contradição. Portanto, dois mais dois devem ser quatro, não é possível ser diferente, da mesma maneira, algo que é verdadeiramente mal não pode não sê-lo. (GROTIUS, 2001, p.10, tradução nossa ${ }^{3}$ )

A importância da razão na distinção do direito natural reverberou no decorrer do século XVIII.Nos limiares da escola do positivismo jurídico a distinção entre o direito positivo e o direito natural baseava-se tanto na fonte como na recepção pelos destinatários. Para Gluck (apud BOBBIO, 1995, p. 21) "chama-se direito natural o conjunto de todas as leis, que por meio da razão fizeram-se conhecer tanto pela natureza, quanto por aquelas coisas que a natureza humana requer como condições e meios de consecução dos próprios objetivos." O direito natural é conhecido, portanto, por meio da razão.

${ }^{3}$ Now the Law of Nature is so unalterable, that it cannot be changed even by God himself. For although the power of God is infinite, yet there are some things, to which it does not extend. Because the things so expressed would have no true meaning, but imply a contradiction. Thus two and two must make four, nor is it possible to be otherwise; nor, again, can what is really evil not be evil. 
O direito positivo, por sua vez, origina-se na vontade de um legislador, é algo que se torna conhecido por meio de uma imposição legislativa ou, em outros termos, uma declaração formal.

Bobbio (1995, p.22/23) sintetiza os critérios de distinção entre o direito natural e o direito positivo:

a) o primeiro [critério] se baseia na antítese universalidade/particularidade e contrapõe o direito natural, que vale em toda parte, ao positivo que vale apenas em alguns lugares (...)

b) o segundo [critério] se baseia na antítese imutabilidade/mutabilidade: o direito natural é imutável no tempo (...)

c) o terceiro critério de distinção, um dos mais importantes, refere-se à fonte do direito e funda-se na antítese, natura-potestas populus.

d) o quarto critério se refere ao modo pelo qual o direito é conhecido, o modo pelo qual chega a nós (isto é, os destinatários) e lastreia-se na antítese ratio-voluntas (Gluck): o direito natural é aquele que conhecemos através de nossa razão. (...) $\mathrm{O}$ direito positivo, ao contrário, é conhecido através de uma declaração de vontade alheia (promulgação);

e) o quinto critério concerne ao objeto dos dois direitos, isto é aos comportamentos regulados por estes: os comportamentos regulados pelo direito natural são bons ou maus por si mesmos, enquanto aqulees regulados pelo direito positivo são por si mesmos indiferentes e assumem uma certa qualificação apenas porque (e depois que) foram disciplinados de um certo modo pelo direito positivo (é justo aquilo que é ordenado, injusto o que é vetado);

f) a última distinção refere-se ao critério de valoração das ações e é enunciado por Paulo: o direito 
natural estabelece aquilo que é bom, o direito positivo aquilo que é útil.

A relação entre esses direitos se alterou no decorrer dos anos. No período clássico o direito positivo era mais valorizado que o natural, por ser considerado mais especializado que este último. $\mathrm{Na}$ Idade Média, por sua vez, esta relação se inverte e o direito natural assume protagonismo, sendo entendido como o direito que origina da vontade de Deus - "lei escrita por Deus no coração dos homens" (BOBBIO, 1995, p. 25)

A dinâmica da relação entre o Direito Natural e o Positivo viria a ser completamente abalada com o surgimento dos Estados Nacionais e o desfazimento das estruturas medievais feudais. Até então ambos possuíam o status de "direito". A unificação da estrutura social na figura do Estado demandava o monopólio deste na produção legislativa, fazendo com que as normas até então produzidas pela sociedade não mais tivessem a conotação jurídica. Jurídica era a norma posta pelo Estado e que seriam efetivamente utilizadas pelos juízes no momento de solução das controvérsias. $O$ advento do positivismo jurídico no final do século XVIII fez com que apenas o direito positivo pudesse ser considerado direito, excluindo o jusnaturalismo de tal categoria.

O jusnaturalismo manteve-se presente, contudo, na cultura jurídica da sociedade e tornou-se forma de integração normativa no caso de lacunas normativas. Para Bobbio (1995, p. 42) “o direito positivo não destrói, mas sim recobre, ou submerge o direito natural; se, portanto, há um "buraco" no direito positivo, através deste se vê aflorar o direito natural; ou, se se preferir, a "submersão" do direito natural não é total, porque, acima do nível do direito positivo, algumas ilhotas ainda afloram” 
As duras críticas positivistas tecidas em desfavor do jusnaturalismo, aliada a uma proposta cientificista no positivismo jurídico abafou expressivamente as discussões envolvendo o direito natural. Em um mundo cada vez mais voltado a um pensamento racionalista e tecnificista, a proposta de abordar o direito com objetividade, neutralidade e distanciamento encontrou imensa guarida.

O jusnaturalismo foi sendo relegado a segundo plano nas disciplinas jurídicas , uma nota histórica, como contraposição à verdadeira ciência do Direito. O cientificismo nas universidades, oriundo do positivismo metodológico, carregava consigo a promessa de verdade nas pesquisas sociais. O positivismo jurídico é objetivo, científico e, portanto, seria superior ao jusnaturalismo cujas bases seriam subjetivas.

A estabilidade positivista pretendida com a objetividade científica, vem, contudo, sofrendo abalos da teoria crítica da ciência, notadamente, das pesquisas na área da hermenêutica. Uma agenda de pesquisa neutra e objetiva torna-se difícil de ser atingida quando o observador/pesquisador está, ele próprio, imerso no seu objeto de pesquisa. .O distanciamento torna-se impossível quando lidamos com as chamadas disciplinas das humanidades. (WEBER, 2006)

Esta revisão do positivismo na filosofia da ciência resvala nas disciplinas jurídicas, atualizando as tensões e recuperando o debate entre o Direito Natural e o Direito Positivo, ressalvando que quando tratamos do Direito a resistência em rever o positivismo jurídico parece ser um pouco mais acentuada.

\section{O JUSNATURALISMO E O DIREITO INTERNACIONAL DOS DIREITOS HUMANOS}


O debate em torno do Direito Internacional resvala, com notável frequência, no tema do jusnaturalismo. Impossível não notar que já nas origens da disciplina está o jusnaturalista Hugo Grotius, cuja definição sobre direito natural já recorremos neste trabalho, acompanhado de teólogos como Francisco de Vitória e Francisco Suárez.

A intimidade com o jusnaturalismo não se deve apenas à sua origem histórica. A organização do sistema internacional pós Segunda Guerra Mundial, baseada na lógica da chamada internacionalização dos Direitos Humanos, demonstra a necessária retomada desta discussão.

A Segunda Guerra Mundial é, sem dúvida, um grande divisor de águas na história política internacional, sendo este evento considerado o grande trauma europeu que viria a modificar toda a organização econômica, social e cultural do continente (e do mundo). A ocorrência de duas grandes guerras em um lapso temporal tão curto demonstrou a necessidade de um novo arranjo que permitisse alguma estabilidade política no continente.

Este novo sistema foi pensado e ganhou corpo com a criação da chamada Organização das Nações Unidas (ONU), uma organização internacional governamental, multilateral, criada com o objetivo de substituir a falida Liga das Nações garantindo a estabilidade e o progresso no pós guerra.

Esta nova ordem internacional inaugurada com a ONU baseiase na necessidade de manutenção da Paz e Segurança Internacionais e preservação dos Direitos Humanos. Estes valores consagrados na comunidade internacional (BULL, 2002) e perseguidos pelos Estados encontram-se expressos na Carta das Nações Unidas como seus propósitos: 
Artigo 1. Os propósitos das Nações unidas são:

1. Manter a paz e a segurança internacionais e, para esse fim: tomar, coletivamente, medidas efetivas para evitar ameaças à paz e reprimir os atos de agressão ou outra qualquer ruptura da paz e chegar, por meios pacíficos e de conformidade com os princípios da justiça e do direito internacional, a um ajuste ou solução das controvérsias ou situações que possam levar a uma perturbação da paz;

2. Desenvolver relações amistosas entre as nações, baseadas no respeito ao princípio de igualdade de direitos e de autodeterminação dos povos, e tomar outras medidas apropriadas ao fortalecimento da paz universal;

3. Conseguir uma cooperação internacional para resolver os problemas internacionais de caráter econômico, social, cultural ou humanitário, e para promover e estimular o respeito aos direitos humanos e às liberdades fundamentais para todos, sem distinção de raça, sexo, língua ou religião; e

4. Ser um centro destinado a harmonizar a ação das nações para a consecução desses objetivos comuns.

A Carta da ONU traduz aqueles valores mais preciosos aos Estados, valores que foram por eles cativados durante a tragédia das duas grandes guerras. O próprio preâmbulo da Carta expressa esta intenção:

(...) preservar as gerações vindouras do flagelo da guerra, que por duas vezes, no espaço da nossa vida, trouxe sofrimentos indizíveis à humanidade, e a reafirmar a fé nos direitos fundamentais do homem, na dignidade e no valor do ser humano, na igualdade de direito dos homens 
e das mulheres, assim como das nações grandes e pequenas, e a estabelecer condições sob as quais a justiça e o respeito às obrigações decorrentes de tratados e de outras fontes do direito internacional possam ser mantidos, e a promover o progresso social e melhores condições de vida dentro de uma liberdade ampla.

E para tais fins praticar a tolerância e viver em paz, uns com os outros, como bons vizinhos, e unir as nossas forças para manter a paz e a segurança internacionais, e a garantir, pela aceitação de princípios e a instituição dos métodos, que a força armada não será usada a não ser no interesse comum, a empregar um mecanismo internacional para promover o progresso econômico e social de todos os povos.

Resolvemos conjugar nossos esforços para a consecução dêsses objetivos.

O "flagelo da guerra" resultou no reconhecimento dos próprios Estados de que era necessário colocar um limite à sua soberania em prol de um bem comum: a paz e a segurança internacionais. A lógica voluntarista que autorizava aos Estados se comportarem livremente e sem amarras, sem qualquer compromisso com as obrigações assumidas, só piorava a insegurança jurídica e instabilidade em um sistema anárquico.

Os Estados passaram a agir conforme uma nova concepção acerca de seu papel no sistema internacional, compartilhando valores que surgiram da própria interação entre eles. A insegurança característica da anarquia do sistema internacional se ameniza pelo surgimento de instituições que possibilitam alguma previsibilidade no comportamento dos atores. (KUBÁLKOVÁ; ONUF, 1998) 
O Direito Internacional é uma dessas instituições que por meio de regras de conduta permite alguma previsibilidade de comportamento e, mais do que isso, permite a difusão de valores que ao mesmo tempo em que são criados pelos Estados também os constituem como agentes, uma verdadeira via de mão dupla em que o agente constitui e é constituído pela instituição. (KUBÁLKOVÁ; ONUF, 1998)

O voluntarismo que um dia caracterizou o Direito Internacional, no qual os Estados contavam apenas com sua vontade, subjetiva, para efetivar o direito, não mais representa o sistema internacional moderno, estabelecido na Carta da ONU. A vontade do Estado sofre limitações pelo Direito Internacional e pelo chamado jus cogens, normas cogentes imperativas que não podem ser derrogadas pela vontade subjetiva dos Estados (TRINDADE, 2015).

A preponderância do jus cogens sobre a vontade dos Estados está prevista na Convenção de Viena sobre Direito dos Tratados $(1969)^{4}$ e expressa uma consciência jurídica internacional para usar das palavras de vários delegados que compuseram a Conferência de Viena de 1968 e 1969, dentre os citados por Trindade (2015, p. 109):

A matéria do jus cogens era o que representou a expressão inegável da 'consciência universal, do denominador comum daquilo que os homens de todas as nacionalidades consideraram como sagrado, ou seja, o

${ }^{4}$ Artigo 53. É nulo um tratado que, no momento de sua conclusão, conflite com uma norma imperativa de Direito Internacional geral. Para os fins da presente Convenção, uma norma imperativa de Direito Internacional geral é uma norma aceita e reconhecida pela comunidade internacional dos Estados como um todo, como norma da qual nenhuma derrogação é permitida e que só pode ser modificada por norma ulterior de Direito Internacional geral da mesma natureza. 
respeito e a proteção dos direitos da pessoa humana. (BRESSON, J.J., delegado da França, apud TRINDADE)

Estados não poderiam, por tratado, ignorar as normas mais elevadas, que foram essenciais para a vida da comunidade internacional, e (que estão) profundamente enraizadas na 'consciência da humanidade' (YASSEN, M. K., depegado do Iraque, apud TRINDADE)

O Direito Internacional é respeitado por representar valores constituídos pelos Estados (e constituintes deles). Nenhum Estado individual (por mais soberana que seja sua vontade) está em posição de contrariar tais valores criados no âmbito da comunidade internacional. Trata-se de violação multilateral que agride a todos os membros daquela comunidade.

Esta concepção de que a ordem internacional deve prevalecer sobre a vontade dos Estados, estampada na Carta da ONU e traduzida na doutrina do jus cogens, balizadora do sistema internacional moderno, nada tem de novo. Francisco de Vitória em suas Relectiones Teológicas (1538-1539) já sustentava que “o ordenamento jurídico obriga a todos - tanto governados como governantes, e, nesta mesma linha de pensamento, que a comunidade internacional (totus orbis) prima sobre o arbítrio de cada Estado individual." (TRINDADE, 2016, p. 19-20)

Esta nova concepção do sistema internacional, primando pela paz e segurança, se sustenta na lógica dos Direitos Humanos ${ }^{5}$ e a

5 Todos os Estados se pautam pela lógica dos Direitos Humanos, ainda que haja discordância sobre qual seria o conteúdo destes Direitos, não existe, hoje, um Estado que se posicione contrário a eles. (DONNELLY, 1996) 
importância de proteção dos indivíduos para além do direito interno (nacional). Há limites para o poder do Estado e este limite é a vida e os direitos de seus jurisdicionados.

Os limites ao poder do Estado vis-à-vis sua população civil já fora objeto de discussão por Hugo Grotius (1625) "Para Grotius o Estado não é um fim em si mesmo, mas um meio para assegurar o ordenamento social consoante a inteligência humana de modo a aperfeiçoar a "sociedade comum que abarca toda a humanidade" (TRINDADE, 2008, p. 199)

A discussão sobre a proteção dos indivíduos até então relegada a objeto de preocupação apenas do nível intra-estatal passa para o internacional, consolidando a chamada internacionalização dos Direitos Humanos cuja agenda, delineada pela Declaração Universal dos Direitos Humanos (1948), torna a referência ao jusnaturalismo demasiadamente óbvia para não ser percebida.

Na concepção de Vitoria, o direito das gentes regula uma comunidade internacional constituída de seres humanos organizados socialmente em Estados e coextensiva com a própria humanidade; a reparação das violações dos direitos humanos reflete uma necessidade internacional atendida pelo direito das gentes, com os mesmos princípios de justiça aplicando-se tanto aos Estados como aos indivíduos ou povos que os formam. (TRINDADE, 2008, p. 198)

A internacionalização dos Direitos Humanos significou a existência do elemento humano em um sistema internacional marcado pelo poder dos Estados. A população civil, até então abafada nas fronteiras estatais, passa a ter existência e protoganismo em nível internacional. Algo que os jusnaturalistas já colocavam como 
fundamento do direito "das gentes". Há de se admirar a ironia de que o Direito Internacional moderno, baseado na lógica dos Direitos Humanos, bebe nas águas do jusnaturalismo. Mais uma vez voltamos a falar em um direito "das gentes" e não meramente "dos Estados".

A própria concepção de Direitos Humanos é jusnaturalista em sua origem. Jack Donnelly (1996, p. 9, tradução nossa ${ }^{6}$ ) nos ensina que "direitos humanos são, literalmente, os direitos que alguém possui simplesmente pelo fato de ser um ser humano". Trata-se de uma concepção universalista em sua base, algo que independe de uma intervenção humana. Para o autor (1996, p. 1, tradução nossa ${ }^{7}$ ):

Se os Direitos Humanos são os direitos que alguém possui simplesmente por ser um ser humano, como geralmente pensado, então são universalmente detidos por todos os seres humanos. Eles também são oponiveis universalmente a todas as pessoas e instituições. Como o mais alto direito moral, regulam as estruturas fundamentais e práticas da vida política, e em circunstâncias ordinárias assumem prioridade sobre outras demandas de ordem moral, legal e política.

A universalidade dos Direitos Humanos é defendida pelo Direito Internacional, inclusive angariando críticas do chamado relativismo cultural que, não sem razão, aponta a origem ocidental e

\footnotetext{
${ }^{6}$ Human Rights are literally the rights one has simply because one is a human being. ${ }^{7}$ If human rights are the rights one has simply because one is a human being, as they usually are thought to be, then they are held "universally", by all human beings. They also hold "universally" against all other persons and institutions. As the highest moral rights, they regulate the fundamental structures and practices of political life, and in ordinary circumstances take priority over other moral, legal, and political claims.
} 
europeia da concepção que se pretende universalizar ${ }^{8}$.Inegável que a base do sistema internacional moderno, como já discorremos, esteja colocada no marco do pós guerra e a partir de uma visão ocidental. Isto se evidencia no próprio contexto de criação da ONU e as necessidades daquele momento histórico.

Ainda assim, com todas as críticas formuladas, o sistema atual de proteção dos Direitos Humanos se sustenta nesta concepção totalizante que garante a cada um dos homens, independente da cultura em que esteja inserido, um mínimo ético irredutível, que não pode ser objeto de violação pelo Estado. (TRINDADE, 2015)

O que sustenta a tese universalista, portanto, não é o positivismo jurídico. Não são leis positivadas, mas sim uma concepção de humanidade, algo inerente ao ser humano e que independe do Estado (tanto independe que a proteção se dá em nível internacional). "O "renascimento" contínuo do direito natural reforça a universalidade dos direitos humanos, porquanto inerentes a todos os seres humanos - em contraposição às normas positivas, que carecem de universalidade, por variarem de um meio social a outro (...)" (TRINDADE, 2008, p. 200)

A presença do jusnaturalismo no Direito Internacional está na base da teoria dos direitos humanos universais, estampados, por sua vez, na Declaração Universal dos Direitos Humanos (1948). Embasa, portanto, toda a discplina do Direito Internacional dos Direitos Humanos que se subdivide em três grandes áreas: Direito Internacional dos Refugiados, Humanitário e Direito Internacional dos Direitos Humanos stricto senso.

8 Defensores do Relativismo cultural defendem que o universalismo expressa um imperialismo cultural europeu, que pretende impor o modo de vida ocidental às culturas orientais. Este é um debate extenso que, infelizmente, não teremos tempo de abordar nestas poucas linhas, ainda que valha a menção. 


\subsection{O Jusnaturalismo no crime contra a humanidade}

O jusnaturalismo está na base de um amplo sistema de proteção aos indivíduos em nível internacional, inclusive em tempos de guerra. O próprio Direito Internacional Penal disciplina que tangencia o Direito Internacional dos Direito Humanos mas se coloca de forma mais autônoma tem em seus fundamentos elementos jusnaturalistas.

O Direito Internacional Penal se diferencia, principalmente, por deter princípios típicos e bem diferentes do Direito Internacional geral, dentre eles, sem dúvida, o princípio da imputação individual é o de maior relevo.

O princípio da Imputação Individual significa que a responsabilidade penal pelos crimes pertence aos indivíduos que os perpetraram, e não aos Estados. O Direito Internacional Penal, em detrimento da legislação interna positivada, pode punir um indivíduo por algo entendido como crime pela comunidade de Estados. Foi o que ocorreu em Nuremberg, onde não havia sequer tipificação para o crime contra a humanidade, mas inúmeros nazistas restaram condenados pelo seu cometimento, com base em uma "consciência" jurídica universal.

Ainda que o ordenamento jurídico alemão permitisse os atos de extermínio, os alemães deveriam saber que aquilo era errado, moralmente, com base em uma consciência jurídica universal. Enquanto seres humanos (independente de serem funcionários públicos ou dentes de engrenagens) eles tinham de saber que matar outros seres humanos era errado.

Pois como os juízes se deram o trabalho de apontar explicitamente, na sala de um tribunal não está em 
julgamento um sistema, uma história ou tendência histórica, um ismo, o anti-semitismo, por exemplo, mas uma pessoa, e se o réu é por acaso um funcionário, ele é acusado precisamente porque até um funcionário ainda é um ser humano, e é nessa qualidade que ele é julgado. (ARENDT, 2004, p.93)

A "humanidade" permeia toda a lógica do Direito Internacional Penal, desde os réus até os tipos penais que visam resguardar essa mesma ideia. Este é o caso do Crime contra a Humanidade, cuja criação como um tipo penal se deu no Tribunal de Nuremberg, gerando as principais críticas a este Tribunal que teria violado os princípios da legalidade e da anterioridade da lei penal (BASSIOUNI, 1984).

De fato não havia, até então, tipo penal positivado que contemplasse os atos de extermínio nazistas, uma matança industrial orquestrada e perpetrada por uma burocracia estatal implacável e destinada à eliminação da população civil. Aquela era uma criminalidade inédita (ARENDT, 2004) que não estava relacionada aos objetivos de guerra. Ao contrário, os campos de extermínio eram contraproducentes, demandavam pessoal e recursos que prejudicavam o esforço bélico. (ARENDT, 2004).

Percebeu-se então que o "crime de guerra" não contemplava sequer metade das matanças perpetradas nos campos de extermínio, bem como as perseguições, deportações e assassinatos dos compatriotas alemães por seus pares. Foi necessário recorrer a um novo tipo penal, o chamado crime contra a humanidade, expressão que havia sido utilizada pela primeira vez em 1915, quando a França, a Grã-Bretanha e a Rússia, por intermédio de uma nota diplomática, consideraram um "crime contra a humanidade e a civilização" o massacre dos Armênios pelos Turcos. (PERRONE-MOISÉS, 2006). 
O crime contra a humanidade foi assim definido em Nuremberg (tradução nossa ${ }^{9}$ ):

Artigo 06 (...) Crimes contra a humanidade: A saber, o assassinato, o extermínio, escravização, deportação e outros atos desumanos cometidos contra a população civil antes da guerra ou durante a mesma; a perseguição por motivos políticos, raciais ou religiosos na execução daqueles crimes que sejam de competência do Tribunal ou em relação aos mesmos, constituam ou não uma violação da legislação interna do país onde se perpetraram.

Criou-se, pós fato, um tipo penal para responsabilizar os nazistas pelas atrocidades cometidas. A legalidade das imputações foi o fato de quehaveria uma responsabilidade pessoal ligada a obrigações assumidas no âmbito internacional. Em outras palavras, segundo o Estatuto dos tribunais, havia uma prática, uma norma consuetudinária internacional de que aquelas condutas não eram permitidas e que os dirigentes deviam saber disso e não ordenar seu cometimento. Argumento, portanto, que resvala escancaradamente no jusnaturalismo: "De Grócio a Vattel, de Martens a Alejandro Álvarez e Barile, a doutrina do direito internacional foi sempre municiada de evocações à consciência humana para estabelecer os fundamentos da disciplina e a validade de suas normas." (TRINDADE, 2015, p. 106)

\footnotetext{
${ }^{9}$ CRIMENES CONTRA LA HUMANIDAD: A saber, el asesinato, la exterminación, esclavización, deportación y otros actos inhumanos cometidos contra población civil antes de la guerra o durante la misma; la persecución por motivos políticos, raciales o religiosos en ejecución de aquellos crímenes que sean competencia del Tribunal o en relación con los mismos, constituyan o no una vulneración de la legislación interna de país donde se perpetraron.
} 
O bem jurídico tutelado é a própria humanidade, trata-se de uma ofensa à pluralidade e à diversidade humana (PERRONIMOISÉS, 2006). o que justifica, inclusive, a responsabilização por um Tribunal Internacional. O crime contra a humanidade, extrapola o corpo das vítimas diretas e atinge a cada um de nós membros desta grande comunidade humana. "O crime contra a humanidade transcende o indivíduo, pois, quando o indivíduo é agredido através de atos inumanos, ataca-se e nega-se toda a humanidade." (PERRONIMOISÉS, 2006, p.218).

Novamente temos a universalidade no Direito Internacional. O Direito Internacional Penal parte da premissa de que existe uma humanidade e ela é um bem jurídico que merece ser tutelado. O crime é justamente eliminar essa humanidade, eliminar a expontaneidade dos homens, transformá-los em animais, sem nome, sem história, sem cultura ou laços sociais.

A justiça penal internacional trouxe de volta ao centro da discussão o indivíduo, a pessoa humana, até então sem lugar no Direito Internacional. A soberania foi ultrapassada pela ideia de dignidade humana. O corpo físico das vítimas, dos homens que sofrem, torna-se mais relevante do que o corpo ficto do Estado.

Ao tutelar o crime contra a humanidade, o Direito Internacional Penal universaliza uma concepção sobre o que é ser humano, independente do que a legislação interna dos Estados prevê. Nesse sentido, nos reportamos ao início desse trabalho e à definição dada por Aristóteles para o Direito Natural como aquele que se aplica em todo lugar igualmente. Independente do que os Estados fizerem, existe uma concepção universal do que é ser humano e violar esta concepcão é um crime tipificado pelo Direito Internacional.

\section{CONCLUSÃO}


A fonte dos Direitos Humanos já denota a herança jusnaturalista. Enquanto o direito positivo tem como fonte a norma legislada (ou costume) e o direito contratual tem como fonte um contrato, os Direitos Humanos têm como fonte a ideia de humanidade (ou condição humana).

A Lei, positivada, pode ser atrelada a um processo legislativo, objetivo e que segue normas procedimentais legitimadoras. Os Direitos Humanos, por sua vez, originam-se daquilo que define os homens enquanto tais e os separa dos demais seres vivos do globo, sua humanidade, suas necessidades.

As demandas por Direitos Humanos traduzem não apenas uma demanda jurisdicional, legal, mas também uma mudança institucional e política, uma verdadeira leitura da realidade. Trata-se de uma área em que o Direito não pode pretender-se neutro e destacado do restante do mundo social. (DONNELLY, 1996)

Como se toda a dominação se resumisse a uma violação jurídica, como se o mal absoluto tivesse agora um nome único que, ao mesmo tempo, o enuncia e incrimina: crime contra a humanidade. Os direitos do homem já não são apenas o baluarte contra a arbitrariedade, passando a ser também um princípio de leitura da realidade. (GARAPON, 2002, p.56)

A distinção entre os direitos positivados e os morais, dentre os quais estão os Direitos Humanos não significa que um seja mais "jurídico" ou mais "direito" que o outro. A diferença é o embasamento que sustenta o direito, sendo que o positivado se baseia de um ato legislativo (ou costumeiro) e o outro da moralidade.para Donnelly (1996, P. 16, tradução nossa): 
Nas sociedades modernas estatais geralmente é mais fácil garantir o cumprimento dos direitos positivos em caso de ameaça ou violação. Mas isso não significa que o direito positivo seja verdadeiramente mais Direito - a menos que alguém arbitrariamente estipule que os únicos verdadeiros direitos são os positivos.(...) Seja direito moral ou positivo, é um Direito.

Neste breve estudo tentamos demonstrar a maneira como o Direito Internacional moderno tem sua gênese em concepções jusnaturalistas, bebendo da fonte dos pais fundadores do direito das gentes. Nem mesmo o Direito Internacional Penal, geralmente tão apegado à "legalidade" positivista escapa do Direito Natural, seja em seus tipos penais (como o crime contra a humanidade), seja na punição de indivíduos (princípio da imputação individual).

A intenção com a escrita deste artigo foi reverberar a discussão acerca da importância do jusnaturalismo para o Direito Internacional. O Direito Natural tem sido relegado a segundo plano nos ensinos jurídicos, excessivamente contaminados por uma ideia cientificista que não representa a realidade das disciplinas humanas e sociais.

A suposta neutralidade científica com a qual se reveste o positivismo jurídico disfarça escolhas políticas e verdadeiros abusos soberanos dos Estados. A busca pelos Direitos Humanos enquanto uma resistência a esta tendência tem sua origem em uma concepção universalista de que a humanidade é algo que existe antes mesmo da criação do Estado. Antes de tudo, somos humanos, ideia jusnaturalista que atravessa o pensamento de Francisco de Vitoria deste o século XVI.

Apesar de seu lugar deslocado e tímido na doutrina jusinternacionalista, o Direito Natural encontra-se presente em manifestações diversas de atores internacionais, como os delegados na 
Conferência de Viena (1968-69) que criou aquela que seria a Convenção fundamental sobre Tratados. A própria concepção de jus cogens nada mais é que a tradução do jusnaturalismo, ao representar uma "consciência jurídica internacional", inerente à comunidade internacional (e que limita os Estados). O jus cogens se destina à proteção de valores universais e não positivados.

Embora o debate sobre o jusnaturalismo apareça apenas como nota histórica face ao positivismo jurídico, na prática do Direito Internacional o jusnaturalismo está vivo e reverberando, ainda que poucos ousem falar dele explicitamente. Uma discussão aberta somente faria enriquecer a doutrina internacionalista. Em um mundo que se estrutura na lógica de direitos humanos universais o debate sobre Direito Natural surge como uma urgência e não um tabu como, lamentavelmente, vem sendo tratado por boa parte da academia.

\section{REFERÊNCIAS}

AMBOS, Kai. A parte geral do Direito Penal Internacional: Bases para uma elaboração dogmática. Ed. brasileira reformada e atualizada. São Paulo: Editora Revista dos Tribunais. 2008.

ARENDT, Hannah. Responsabilidade e julgamento. São Paulo: Companhia das Letras, 2004.

BASSIOUNI, M. Cherif. Derecho penal internacional: proyecto de código penal internacional. Madrid: Tecnos, 1984 
BAZELAIRE, Jean-Paul; CRETIN, Thierry. A justiça penal internacional: sua evolução, seu futuro : de Nuremberg a Haia. Barueri: Manole, 2004.

BOBBIO, Norberto. O positivismo jurídico: Lições de filosofia do Direito. São Paulo: Ícone, 1995.

BULL, Hedley. A sociedade anárquica: um estudo da ordem na política mundial. São Paulo: Universidade de Brasília, 2002.

CARTA DAS NAÇÕES UNIDAS (1945). Disponível em $<$ http://www.planalto.gov.br/ccivil_03/decreto/19301949/D19841.htm> Acesso em 21 de dezembro de 2016

CONVENÇÃO DE VIENA SOBRE DIREITO DOS TRATADOS (1969). Disponível em

<http://www.planalto.gov.br/ccivil_03/_ato20072010/2009/decreto/d7030.htm> Acesso em 22 de dezembro de 2016

DONNELLY, Jack. Universal Human Rights in Theory \& Practice. New York: Cornell University Press, 1996

ESTATUTO DO TRIBUNAL DE NUREMBERG. Disponível em $<$ http://www.cruzroja.es/dih/pdf/estatuto_del_tribunal_militar_inter nacional_de_nuremberg.pdf> Acesso em 20 de dezembro de 2016

GARAPON, Antoine. Crimes que não se podem punir nem perdoar: Para uma justiça internacional. Lisboa: Instituto Piaget, 2002.

GROTIUS, Hugo. On the Law of war and peace. Kitchener: Batoche Books, 2001 
KUBÁLKOVÁ, V.; ONUF, Nicholas Greenwood; KOWERT, Paul. International relations in a constructed world. Armonk: M. E. Sharpe, 1998.

LAFER, Celso. A reconstrução dos direitos humanos: um diálogo com o pensamento de Hannah Arendt. São Paulo: Companhia das Letras, c1988.

MAGALHÃES, Thereza Calvet de. Ação, linguagem e poder: uma releitura do capítulo $\mathrm{V}$ da obra The Human Condition. In: CORREIA, Adriano (org.). Hannah Arendt e a condição humana. Salvador: Quarteto. 2006

PERRONE-MOISÉS, Cláudia. O perdão e os crimes contra a humanidade: um diálogo entre Hannah Arendt e Jacques Derrida. In: CORREIA, Adriano (org.). Hannah Arendt e a condição humana. Salvador: Quarteto. 2006

TRINDADE, Antônio Augusto Cançado. A humanização do Direito Internacional. Belo Horizonte: Del Rey, 2015

TRINDADE, Antônio Augusto Cançado. Totus Orbis: A visão universalista e pluralista do jus gentium: sentido e atualidade da obra de Francisco de Vitoria. Revista da Academia Brasileira de Letras Jurídicas, Rio de Janeiro, ano XXIV, n. 32-33, p. 197-212, 2008

TRINDADE, Antônio Augusto Cançado. Prefácio. In. VITÓRIA, Francisco de. Relectiones sobre os índios e sobre o poder civil. Brasília: Editora UNB Fundação Alexandre de Gusmão, 2016 
VATTEL, Emer de. O direito das gentes. Brasília: Editora Unb: Instituto de Pesquisa de Relações Internacionais, 2004

WEBER, Max. A objetividade do conhecimento nas ciências sociais; tradução, apresentação e comentários Gabriel Cohn. São Paulo: Ática, 2006.

WEBER, Max. Economia e sociedade: fundamentos da sociologia compreensiva. 4. ed. Brasília: Ed. UnB; São Paulo: Imprensa Oficial, 2004. 